\title{
The Comparison of Glass Ceiling Perception of Employees Working in Public and Private Enterprises
}

\author{
Hanifi Sever \\ Zonguldak Police Department, TNP, Zonguldak, Turkey \\ Email: drhanifisever@gmail.com
}

Received 12 April 2016; accepted 13 May 2016; published 16 May 2016

Copyright (C) 2016 by author and Scientific Research Publishing Inc.

This work is licensed under the Creative Commons Attribution International License (CC BY).

http://creativecommons.org/licenses/by/4.0/

(c) (i) Open Access

\begin{abstract}
Glass ceiling syndrome can be described as invisible and unbreakable barriers that keep a special group, such as women or any minorities, from progressing in their professional career, regardless of their ability or qualifications. Unseen barriers prevent women from promotion and, workforce. Gender-based discrimination in promotions is more intense at higher levels, but it is felt in every stage of business life. In this study, the glass ceiling perception of men and women employees working in public and private sectors was targeted by evaluating some variables. As a result of the study, it is expressed that women confront the glass ceiling syndrome much more than men. The factors affecting the glass ceiling were identified as gender, age, marital status, promotion, working in public or private sector and additional income.
\end{abstract}

\section{Keywords}

Glass Ceiling, Gender Discrimination, Work Environment, Women Executives, Career Development

\section{Introduction}

The development of education and information technology and understanding the importance of women's work have resulted in an increase of the number of women employees. The increase in the quality and capacity of their work in the service sector has brought about some changes in the social structure.

Glass ceiling on the basis of gender can be defined as limiting the chance for promotion, duties and responsibilities by invisible organizational or perceptual barriers [1]-[3].

Women encounter the glass ceiling in their careers particularly in the areas of work authority, prestige, trust, wages, being kept at a secondary role in terms of responsibility and duty. This ambivalence is not expressed 
bluntly, in contrast; it is expressed implicitly by rather preferring men in the organizational structure.

Lockwood (2004) dealt with exposure of women to the glass ceiling syndrome in three different dimensions: 1 -women are not more ambitious in working life compared to men; 2 -pressure between family responsibilities and incurred tasks; 3-the glass ceiling syndrome occurs around high positions in business life. As such, it has been pointed out that managerial rank and high positions increase the rigor of glass ceiling syndrome [2].

In this study, the glass ceiling perception of men and women employees working in public and private sectors was targeted by evaluating some variables. As a result of the study, it is expressed that women confront the glass ceiling syndrome much more than men. The factors affecting the glass ceiling were identified as gender, age, marital status, promotion, working in public or private sector and additional income.

\section{Literature Review}

Society is composed of individuals. Individuals, constituting society from the moment they were born, have a social gender at every stage of their life besides they have a gender of their own. Attributed gender characteristics vary according to the societies. For example, "men do not cry" and "Cry, you can relax" statements are traditionally used for men and women respectively in the Turkish society [4].

Gender discrimination is a taboo that exists as an invisible hierarchy in every society. This hierarchy can be associated with dominance or force acquisition in social roles [5].

Gender differences caused development of the concept of division of labor and stakeholders in society. Accordingly, specific roles and duties for men and women in society are determined by an invisible network. Bhasin (2003) claims that tasks given to the boys and girls are not based on personal preferences and abilities but on the social norms of the society [6].

There are many theories explaining the problems experienced due to gender differences. The common point of these theories is their attempt to explain why women have stayed at the background rather than men.

Albert Bandura's Social Cognitive Theory explains the gender development and its differentiation. Individual, environmental and behavioral factors affect the perception of community. On the other hand, according to social learning theory, modeling, direct experience and learning are highly essential [7].

Lawrence Kohlberg's Cognitive Development Theory, originally conceived by Swiss psychologist Jean Piaget, states that the individual learns to behave himself in the presence of appropriate gender socialization. Cognitive consistency develops simultaneously with child's growth. So, a child gains the rules of moral behavior and immutable stereotypes according to gender [8].

Sandra Lipsitz Bem's Gender Schema Theory can be described as the intersection of social learning and cognitive development theories. Individuals have coded the sexual differences related to the definition of cultural diversity. In this theory, there is an inverse relationship between the masculine behavior and feminine posture. "Androgyny" definition related to Bem Sex-Role Inventory (BSRI) is a measure of masculinity, feminity and gender roles, which defines how people identify themselves. "Androgyny" describes individuals feminine or masculine depending on the individual and environmental factors [9] [10]. In this study, androgens expressed that they provided a more harmonious and a successful adaptation to society.

Alice Eagly's Social Role Theory expresses that men and women in society have different status. She worked on various fields such as prejudice, sex differences, and attitudes. This theory attributes current gender differences to the labor division between men and women [11]. Especially, if task and status of women increase in managerial areas, it is said to decrease gender discrimination. Social pressure is a factor affecting the behavior of individuals. Therefore, if the role differences between men and women decrease, so does the social discrimination [12].

Percent of employment according to marital status of men and women in Turkey is depicted in Table 1. Between 2004 and 2013, the number of working single women increased 4.7\%. In the same period, the proportion of married women in business life increased $8.9 \%$. The $10 \%$ increase of the divorced laboring women is also noteworthy.

Considering women in business life in Turkey, there are three different groups. These are unpaid workers in family businesses in the agricultural sector, low skilled employees in low paid labor-intensive business area, and finally highly trained employees [13].

Table 2 displays the sectorial distribution of individual employees by gender. Men and women in the service sector increased to almost equivalent proportions in approximately a decade. On the other hand, there is a sig- 
Table 1. Household labor force statistics by gender (www.tuik.gov.tr).

\begin{tabular}{cccccccc}
\hline & \multicolumn{2}{c}{ 2004 (\%) } & \multicolumn{2}{c}{ 2009 (\%) } & \multicolumn{2}{c}{ 2013 (\%) } \\
\cline { 2 - 7 } & Female & Male & Female & Male & Female & Male \\
\hline Single & 33.2 & 56.3 & 36.2 & 59.5 & 37.9 & 61.4 \\
Married & 21.6 & 77.5 & 24.3 & 76.5 & 30.5 & 77.3 \\
Divorced & 40.9 & 73.3 & 45.8 & 71.1 & 50.9 & 72.9 \\
Widowed & 9.1 & 23.5 & 9 & 20.7 & 9 & 19.5 \\
\hline
\end{tabular}

Table 2. Sectorial distribution of the employees by gender (www.tuik.gov.tr).

\begin{tabular}{ccccccc}
\hline & \multicolumn{2}{c}{$\mathbf{2 0 0 4}(\mathbf{\%})$} & \multicolumn{2}{c}{ 2009 (\%) } & \multicolumn{2}{c}{ 2013 (\%) } \\
\cline { 2 - 7 } & Female & Male & Female & Male & Female & Male \\
\hline Agriculture & 51 & 22 & 42 & 18 & 37 & 18 \\
Industry & 16 & 22 & 15 & 21 & 15 & 22 \\
Construction & 1 & 6 & 1 & 8 & 1 & 10 \\
Service & 33 & 50 & 43 & 53 & 48 & 51 \\
\hline
\end{tabular}

nificant reduction of ratio of women in the agricultural sector, while those working in the industry stay relatively unchanged.

Considering the distribution of residence of men and women, those rates working in public or private sector are very close together (Table 3).

According to a study [14], women working in management positions in the public sector is $16 \%$ and there are only 530 women top managers.

According to another survey on managers based on gender, female managers are more successful on emotional intelligence and empathy and prone to team work and cooperation than males. Additionally, women have been preferred over men for being more patient by employers [15]. However, promoting to managerial position is extremely difficult for women due to the fact that women are less competitive and reckless [16]. This claim can be defined as the core of gender discrimination in management.

Terzioğlu and Taşkın's (2008) study [17] states that men are more independent and they can eliminate the unfavorable issues easily than women when they decide to do something. In managerial process, women are integrative and polite, focused on details and use appropriate expressions while men are rigid, stable, and authoritative and advocate discrimination if they feel it is required [18].

\section{Methodology}

A scale originally constructed by Karaca [19], which was tested/retested for validity and reliability, was prepared to measure the perception of glass ceiling syndrome. In this scale in Appendix, the problems that women face during their career are divided into three main sections: Individual, organizational and social obstacles. The three main groups have eight sub-dimensions (Table 4).

Undertaking multiple roles refers to the struggle of caring for the home and children while progressing in the professional career. Various responsibilities of women in their life summarize the women's undertaking of multiple roles.

Women's personal perceptions should be evaluated at the same level as undertaking multiple roles. Considering the cognitive or behavioral dimension, women may be more prone to professional deterioration, occupational burnout, and fatigue sensations. Thus, withdrawals, exhaustion, lack of enthusiasm, and cynicism in women's personal perception are severe factors distorting motivation in their life.

Organizational culture represents the collective values, beliefs and principles of members of the organization and is a product of factors such as history, type of employees, management style, and national culture. Culture 
Table 3. Gender/sector distribution by residence (www.tuik.gov.tr).

\begin{tabular}{cccccccc}
\hline & \multicolumn{2}{c}{ Turkey (\%) } & \multicolumn{2}{c}{ Urban (\%) } & \multicolumn{2}{c}{ Rural (\%) } \\
\cline { 2 - 7 } & Female & Male & Female & Male & Female & Male \\
\hline Private sector & 85.1 & 87.1 & 79 & 85.9 & 94 & 89.6 \\
Public agencies & 12.9 & 12.5 & 19 & 13.6 & 4.2 & 9.9 \\
Others & 2 & 0.4 & 2.1 & 0.5 & 1.8 & 0.4 \\
\hline
\end{tabular}

Table 4. Gender-based barriers on glass ceiling.

\begin{tabular}{ccc}
\hline & Discriminatory gender-based barriers on glass ceiling & \\
\hline Individual obstacles & Organizational obstacles & Social obstacles \\
\hline Undertaking multiple roles & Organizational culture & Occupational segregation \\
Women's personal perceptions & Organizational policies & Stereotypes \\
& Mentor deficiency & \\
\hline
\end{tabular}

includes the organization's vision, values, norms, systems, symbols, language, assumptions, beliefs, and habits [19] [20].

Organizational policies are associated with the decisions of the senior managers of the organization and the organizational culture. In order to achieve the development goals of organization, it can be taken some managerial decision on human resources bound to gender. The policy to send only male employees to overseas offices of the organization is an example.

Mentoring can be described as seeking help from someone to reach out knowledge. The combination of the knowledge is an important factor in the career. Physical conditions of the working environment and cultural elements block mentoring.

Avoiding informal networks explains person who refuses or avoids participating in the social events at the workplace. Compared to men, women are less likely to take part in coffee breaks, tieless meetings or social meetings that increase the harmony among employees [21] [22]. Therefore, avoidance of social events is believed to be an important factor of the glass ceiling effect.

Occupational segregation refers to gender discrimination regarding cultural attitudes. It is the distribution of people across and within jobs and tasks, based on gender differences. For example, execution of the profession may vary between men and women according to the social perception.

Stereotypes refer to the prejudices and stereotypical perception of the behavior of women and men in society. For instance, masculinity is a set of attributes, behaviors, roles and male-dominated jobs based on physical and mental force such as policing, being a top manager are generally associated with masculinity.

In this study; volunteers working in the public and private sectors in Istanbul province between 01/11/2015 and 30/12/2015 were included. For private enterprises 10 companies operating in the field of international trade were chosen. The chiefs of human resources department in these companies were contacted and all the employees were invited to participate in the study.

In the public sector, civil servants working at the governorate's sub-units (directorate of education, population, internal revenue, hospitals, police department, etc.) were included. Administrative employees in the public sector were reluctant to participate; therefore volunteers from all entities were included in the study.

All subjects participating in the study had a possibility of promotion in their occupation. Employees with no possibility of promotion were excluded.

With the help of the chiefs of the human resources departments of companies and institutions, questionnaires and scales were sent by electronic mail to all employees and feedbacks were requested.

782 participants from the ten private enterprises have a possibility of promotion. The number of employees in the public sector could not be counted. 651 employees participated in the study. 
The data collection materials consisted of two parts. The first part measured the perception of gender discrimination using Karaca (2007)'s scale of glass ceiling syndrome. There are eight subscales under three main headings of this scale. Cronbach's alpha value of the questionnaire was measured as 0.800 . In the second part, socio-demographic characteristics of participants were surveyed.

The answers given to the questionnaire were analyzed and results have been interpreted by SPSS (ver 20.0.) software.

\section{Results}

The youngest of 651 participants of the study was 21 years old, while the oldest was 48 . The average age was 29.1.

Almost all of the participants (93.2\%) were female. Women are the majority and it is important in measuring the glass ceiling perception. Half of those (52.8\%) graduated from vocational school or higher. $44.2 \%$ of them were in the public sector, working as a civil servant, the rest worked in the private sector. $70.7 \%$ were married and $56.4 \%$ had dependents. $54.9 \%$ of them described their financial status as moderate or good. Most (69.7\%) expressed that they had additional fixed income contributing to the family budget. Nearly half of the employees who participated in the study (48.5\%) expected promotion (Table 5).

When the glass ceiling syndrome and sub dimensions' descriptive statistics $\left(\mathrm{X}_{\text {mean }}\right)$ are examined; it can be said that the existence of glass ceiling syndrome is a phenomenon (Table 6).

The joint impact of gender and age on the glass ceiling was not statistically significant $(p=0.107, p>0.05$; tested by Univariate Analysis of Variance). Men and women did not differ depending on the age for the perception of the glass ceiling (Table 7).

There was a negative correlation between all the determined variables and perceived glass ceiling syndrome. When age, tenure, number of children, awards and promotions increased, the perception of glass ceiling decreased (Table 8).

When the correlation between the scale of the dimensions of the glass ceiling syndrome was examined (Table 9), there was a:

Table 5. Socio-demographic characteristics of the sample.

\begin{tabular}{|c|c|c|c|c|c|}
\hline Highest education & $\mathbf{n}$ & $\%$ & Financial status & $\mathbf{n}$ & $\%$ \\
\hline High school & 53 & 8.1 & Very bad & 132 & 20.3 \\
\hline Vocational school & 344 & 52.8 & Bad & 161 & 24.7 \\
\hline University & 252 & 38.7 & Moderate & 135 & 20.7 \\
\hline \multirow[t]{2}{*}{ Graduate school } & 2 & 0.3 & Good & 159 & 24.4 \\
\hline & & & Very good & 64 & 9.8 \\
\hline Gender & $\mathbf{n}$ & $\%$ & Marital status & $\mathbf{n}$ & $\%$ \\
\hline Female & 607 & 93.2 & Married & 460 & 70.7 \\
\hline Male & 44 & 6.8 & Single & 191 & 29.3 \\
\hline Sector & $\mathbf{n}$ & $\%$ & Dependent people (children etc.) & $\mathbf{n}$ & $\%$ \\
\hline Civil servants & 363 & 44.2 & Yes & 367 & 56.4 \\
\hline Private sector employees & 288 & 55.8 & No & 284 & 43.6 \\
\hline Promotion expectation & $\mathbf{n}$ & $\%$ & Additional income & $\mathbf{n}$ & $\%$ \\
\hline Yes & 226 & 34.7 & Yes & 454 & 69.7 \\
\hline No & 316 & 48.5 & No & 197 & 30.3 \\
\hline Not sure & 109 & 16.7 & & & \\
\hline Total & 651 & 100.0 & Total & 651 & 100.0 \\
\hline
\end{tabular}


Table 6. Descriptive statistics of the sub dimensions of glass ceiling syndrome scale.

\begin{tabular}{ccccccc}
\hline Sub-dimensions & $\mathbf{n}$ & Min & Max & $\mathbf{X}_{\text {mean }}$ & St D. \\
\hline Undertaking multiple roles & 651 & 1.20 & 4.80 & 3.2633 & .62180 \\
Women's personal perceptions & 651 & 1.00 & 5.00 & 3.2813 & .86082 \\
Organizational culture and policies & 651 & 1.88 & 4.50 & 3.4215 & .54969 \\
Avoiding to informal networks & 651 & 1.00 & 5.00 & 3.4322 & .60338 \\
Mentor deficiency & 651 & 1.00 & 5.00 & 3.5862 & 1.18619 \\
Occupational segregation & 651 & 1.67 & 5.00 & 3.2893 & .85950 \\
Stereotypes & 651 & 1.00 & 5.00 & 2.9691 & .86205 \\
\hline
\end{tabular}

Table 7. Univariate analysis of variances and glass ceiling syndrome.

\begin{tabular}{ccccc}
\hline & F & df1 & df2 & Sig. \\
\hline Glass ceiling syndrome & 1.320 & 5 & 13 & 0.107 \\
\hline
\end{tabular}

Table 8. Correlation analysis of some variables and glass ceiling syndrome.

\begin{tabular}{cccccc}
\hline & \multicolumn{5}{c}{ Correlation coefficients } \\
\cline { 2 - 6 } & Age & Tenure & Children & Awards & Promotion \\
\hline Glass ceiling syndrome & $-0.391\left(^{* *}\right)$ & $-0.361\left(^{* *}\right)$ & $-0.288\left(^{* *}\right)$ & $-0.671\left(^{* *}\right)$ & $-0.788\left(^{* *}\right)$ \\
\hline
\end{tabular}
${ }^{*} p<0.05 ;{ }^{* *} p<0.01$.

Table 9. Correlation analysis of the dimensions of the glass ceiling syndrome.

\begin{tabular}{|c|c|c|c|c|c|c|c|c|}
\hline & \multirow{2}{*}{ Sub dimensions } & \multicolumn{5}{|c|}{ Correlation coefficients } & \multirow[b]{2}{*}{6} & \multirow[b]{2}{*}{7} \\
\hline & & 1 & 2 & 3 & 4 & 5 & & \\
\hline 1 & Undertaking multiple roles & - & & & & & & \\
\hline 2 & Women's personal perceptions & $0.471\left(^{* *}\right)$ & - & & & & & \\
\hline 3 & Organizational culture and policies & $0.611\left(^{* *}\right)$ & $0.592\left(^{* *}\right)$ & - & & & & \\
\hline 4 & Avoiding informal networks & 0.054 & $0.347\left(^{* *}\right)$ & $0.199\left(^{* *}\right)$ & - & & & \\
\hline 5 & Mentor deficiency & $-0.234\left(^{* *}\right)$ & $-0.351\left(^{* *}\right)$ & $-0.314\left(^{* *}\right)$ & $0.115\left(^{* *}\right)$ & - & & \\
\hline 6 & Occupational segregation & -0.056 & 0.072 & $-0.102\left(^{* *}\right)$ & $0.286\left(^{* *}\right)$ & $0.567\left(^{* *}\right)$ & - & \\
\hline 7 & Stereotypes & -0.033 & $0.105\left(^{* *}\right)$ & $-0.130\left(^{* *}\right)$ & $0.252\left(^{* *}\right)$ & $0.541\left(^{* *}\right)$ & $0.699\left(^{* *}\right)$ & - \\
\hline
\end{tabular}

${ }^{*} p<0.05 ;{ }^{* *} p<0.01$.

- positive correlation between multiple roles and women's personal perceptions $(\mathrm{r}=0.471, p<0.01)$, organizational culture and policies $(\mathrm{r}=0.611, p<0.01)$, negative correlation with mentor deficiency $(\mathrm{r}=-0.234, p<$ $0.01)$.

- positive correlation between women's personal perceptions and organizational culture and policies $(\mathrm{r}=0.592$, $p<0.01$ ), informal networks ( $\mathrm{r}=0.347, p<0.01$ ), stereotypes $(\mathrm{r}=0.105, p<0.01)$, negative correlation with mentor deficiency $(\mathrm{r}=-0.351, p<0.01)$.

- positive correlation between organizational culture and policies and informal networks $(\mathrm{r}=0.199, p<0.01)$, negative correlation with mentor deficiency $(\mathrm{r}=-0.314, p<0.01)$, stereotypes $(\mathrm{r}=-0.130, p<0.01)$ and Occupational segregation $(r=-0.102, p<0.01)$. 
- positive correlation between informal networks and mentor deficiency $(\mathrm{r}=0.115, p<0.01)$ and stereotypes ( $\mathrm{r}$ $=0.252, p<0.01$.

- positive correlation between mentor deficiency and Occupational segregation ( $r=0.567, p<0.01)$, stereotypes $(\mathrm{r}=0.541, p<0.01)$.

- positive correlation between Occupational segregation and stereotypes $(r=0.699, p<0.01)$.

Glass ceiling syndrome and its sub dimensions were analyzed with several variables using the Independent Sample t Test (Table 10).

In the glass ceiling syndrome, statistically significant difference was observed between gender $(p=0.000)$, marital status $(p=0.001)$, promotional expectations $(p=0.004)$, working in public or private sector $(p=0.000)$ and several demographic variables. Additional income was not a specific determinant of glass ceiling $(p=$ 0.119).

According to results in Table 9, women and married ones feel the effect of the glass ceiling syndrome more severe than their peers. Similarly, private sector employees with promotional expectations expressed that they felt the glass ceiling more than their counterparts.

When analyzed in terms of sub-dimensions; mentor deficiency, occupational segregation and perceptions of stereotypical bias created a statistically significant difference.

The effects of independent variables on the glass ceiling perception were examined by multiple regression analysis. When analyzed the model summary, independent variables were found to explain $70 \%$ of the variance $\left(\mathrm{R}^{2}=0.704\right)$ of the glass ceiling perception.

All of the tested independent variables of the glass ceiling perception, gender, sector difference, additional income, marital status, and promotion expectations, were significant predictors of the perception of the glass ceiling (Figure 1).

Table 10. Glass ceiling and its sub-dimensions analysis with some variables (Independent Sample t test).

\begin{tabular}{|c|c|c|c|c|c|c|}
\hline & & Gender & Marital status & Promotion expectation & Sector & Additional income \\
\hline \multirow{2}{*}{ Glass ceiling syndrome } & $\mathrm{t}$ & -4.838 & -3.433 & 2.899 & 8.883 & 1.560 \\
\hline & $\mathrm{p}$ & 0.000 & 0.001 & 0.004 & 0.000 & 0.119 \\
\hline \multirow{2}{*}{$\begin{array}{l}\text { Undertaking } \\
\text { multiple roles }\end{array}$} & $\mathrm{t}$ & 0.197 & -0.476 & 1.845 & 1.012 & 0.238 \\
\hline & $\mathrm{p}$ & 0.844 & 0.634 & 0.066 & 0.312 & 0.812 \\
\hline \multirow{2}{*}{$\begin{array}{l}\text { Women's } \\
\text { personal perceptions }\end{array}$} & $\mathrm{t}$ & -1.357 & -0.884 & 1.145 & 3.364 & 0.100 \\
\hline & $\mathrm{p}$ & 0.114 & 0.377 & 0.253 & 0.001 & 0.921 \\
\hline \multirow{2}{*}{$\begin{array}{l}\text { Organizational } \\
\text { culture and policies }\end{array}$} & $\mathrm{t}$ & 0.616 & 1.096 & -0.177 & -1.907 & -0.470 \\
\hline & $\mathrm{p}$ & 0.441 & 0.273 & 0.437 & 0.045 & 0.639 \\
\hline \multirow{2}{*}{$\begin{array}{c}\text { Avoiding } \\
\text { informal networks }\end{array}$} & $\mathrm{t}$ & -0.600 & 0.362 & -1.037 & 1.336 & 1.557 \\
\hline & $\mathrm{p}$ & 0.488 & 0.717 & 0.314 & 0.194 & 0.015 \\
\hline \multirow{2}{*}{ Mentor deficiency } & $\mathrm{t}$ & -2.940 & -2.261 & 0.211 & 5.597 & 2.230 \\
\hline & $\mathrm{p}$ & 0.000 & 0.017 & 0.833 & 0.000 & 0.026 \\
\hline \multirow{2}{*}{ Occupational segregation } & $\mathrm{t}$ & -5.497 & -5.628 & 4.610 & 12.168 & 1.841 \\
\hline & $\mathrm{p}$ & 0.000 & 0.000 & 0.000 & 0.000 & 0.066 \\
\hline \multirow{2}{*}{ Stereotypes } & $\mathrm{t}$ & -4.693 & -3.987 & 2.902 & 9.598 & 1.524 \\
\hline & $\mathrm{p}$ & 0.000 & 0.000 & 0.004 & 0.000 & 0.128 \\
\hline
\end{tabular}




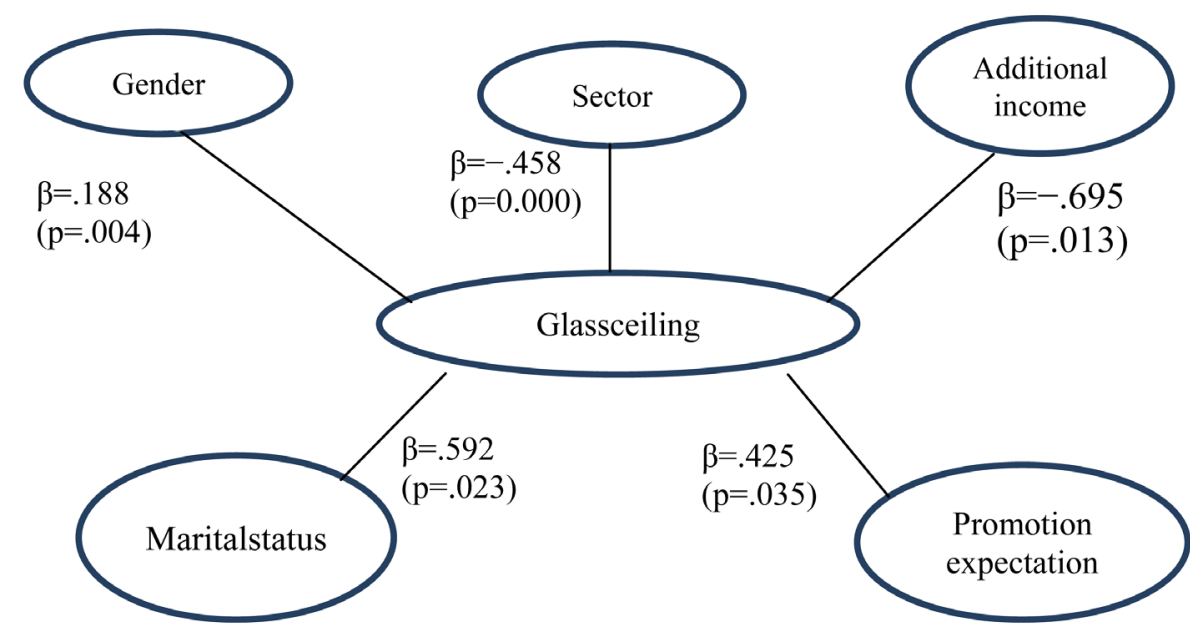

Figure 1. The variables of regression model in glass ceiling syndrome.

\section{Discussion}

Since almost all of the participants had a vocational school degree or higher, promotional possibilities seem to be very important for them. Considering sub-dimensions, it can be said that the intensity of glass ceiling perception is in moderate level.

In previous studies [23]-[25], women expressed eagerness to participate in career training, to develop social relationships, and to show high performance in order to break the hard glass ceiling. In this study, women who face the glass ceiling appear to accept it rather than struggle with it. The increase of age, tenure, number of children, awards, and promotion was found to decrease the glass ceiling perception. From this perspective, employees become accustomed to the glass ceiling syndrome during their career. They may partially give up their ideals and their priorities might change in the life or their families may become their first priority. Depending on age and seniority at work, being "old" can be explanatory. This idea may be explained by Alice Eagly's Social Role Theory. The increasing status of women in business life has led to reduction of the gender discrimination cases [12].

A strong correlation among the subscales was observed. Undertaking multivariate role of women in the work and family life is important to influence their personal perceptions and organizational culture/policies. Furthermore, it is noteworthy that there is a linear correlation between organizational culture/policies and informal networks including external business facilities. Women are believed to participate informal networks less than their male counterparts [22] [26]. In this context, using the informal networks should be accepted as an important issue when considered with organizational culture and policies.

The increasing occupational segregation referring gender differences was observed to affect the stereotypical bias in the same direction $(\mathrm{r}=.699, p<0.01)$. Therefore, women working in perceived masculine occupations may face much higher stereotypical bias.

Bhasin (2003) examines the role of gender-specific social norms [6]. The boys and girls in society are given the tasks granted by social norms, not according to personal preferences and abilities. Thus, social norms are thought to play an important role in the formation of stereotypical prejudices. In this study, a difference in the perception of the glass ceiling between men and women was observed. Women felt facing more obstacles than men did. Similarly, those who were married, those who expected promotion and those who worked in private sectors expressed that they felt glass ceiling effect more than their peers. Thus, disappointment in promotion leads to decrease the tension of glass ceiling effect. As Hirata et al. [5] pointed out, glass ceiling based on gender discrimination and hierarchy was associated with a dominance or force acquisition in social roles.

Married women, who undertake the responsibilities of the job and the household tasks, felt the barriers more than men. Therefore, roles of women in society affect the glass ceiling perception and change women's priorities such as family responsibilities.

Gender, employment status (private or public employee), having additional income, marital status and promotion expectations were significant predictors of the glass ceiling syndrome. Thus, these predictors can be listed as factors which influence the intensity of glass ceiling perception. 


\section{Conclusions}

The analysis in this study, including 651 participants, showed that women confront the glass ceiling more than men. The differences which can be attributed to diverse variables can be explained by social roles in society.

In this study, participants' sample is an important limitation to explain why women expose to gender differences in their professionals. However, acceptable findings to identify the glass barriers have been determined by using a tested/retested scale.

Is the glass ceiling phenomenon surrounded by invisible walls in organizations a coincidence? This study suggests some essential empirical answers. Undertaking multiple roles, organizational culture and policies, women's personal perceptions, using informal networks, mentor deficiency, occupational segregation and stereotypes should be considered when we try to deal with discrimination in businesses.

The most important conclusion of this study is the identification of the predictors of discrimination in organizations. Gender, employment status, having additional income, marital status and promotion expectations are significant predictors of the glass ceiling syndrome.

\section{References}

[1] Elacqua, T.C., Beehr, T.A., Hansen, C.P. and Webster, J. (2009) Managers’ Beliefs about the Glass Ceiling: Interpersonal and Organizational Factors. Psychology of Women Quarterly, 33, 285-294. http://dx.doi.org/10.1177/036168430903300304

[2] Lockwood, N. (2004) The Glass Ceiling: Domestic and International Perspectives. Human Resource Magazine Research Quarterly, 1-49.

[3] Weyer, B. (2007) Twenty Years Later: Explaining the Persistence of the Glass Ceiling for Women Leaders. Women in Management Review, 22, 482-496. http://dx.doi.org/10.1108/09649420710778718

[4] Kirman, M.A. (2011) The Glossary of Religion Sociology, Second Press. Ragbet Publication Press, İstanbul.

[5] Hirata, H., Laborie, F., Le Doare, H. and Senotier, D. (2009) The Dictionary of Feminist Theory. Translated by G. Acar-Savran, Kanat Kitap Publication, İstanbul.

[6] Bhasin, K. (2003) Gender. Translated by K. Ay, Kadın Dayanışma Vakfı Publication, İstanbul.

[7] Bandura, A. (2001) Socialcognitivetheory: An Agenticperspective. Annualreview of psychology, 52, 1-26. http://dx.doi.org/10.1146/annurev.psych.52.1.1

[8] Kohlberg, L. (1984) The Psychology of Moral Development: The Nature and Validity of Moral Stages. Vol. 2. Harpercollins College Div.

[9] Bem, S.L. (1974) The Measurement of Psychological Androgyny. Journal of Consulting and Clinical Psychology, 42, 155-162. http://dx.doi.org/10.1037/h0036215

[10] Bem, S.L. (1977) On the Utility of Alternative Procedures for Assessing Psychological Androgyny. Journal of Consulting and Clinical Psychology, 45, 155-162. http://dx.doi.org/10.1037/0022-006x.45.2.196

[11] Aries, E. (1996) Men and Women in Interaction: Reconsidering the Differences. Oxford University Press.

[12] Eagly, A.H., Wood, W. and Diekman, A.B. (2000) Social Role Theory of Sex Differences and Similarities: A Current Appraisal. In: Eckes, T. and Trautner, H.M., Eds., The Developmental Social Psychology of Gender, Psychology Press, Taylor \& Francis Group, New Jersey, 123-174.

[13] Ilkkaracan, I. (1998) Urban Women and Work Life. Bilanço 98: 75 Yılda Kadınlarve Erkekler. Tarih Vakfi Publication, Istanbul, 285-302.

[14] Negiz, N. and Yemen, A. (2011) FemaleAdministrators in Public Organizations: Female Problematique in Administration in Terms of Administrator and Employee. Süleyman Demirel University Faculty of Arts and Sciences Journal of Social Sciences, 24, 195-214.

[15] Mercanlıoğlu, Ç. (2009) Gender-Based Inequality; Executives Challenges and Costs of Women Balancing Work and Private Lives. International-Interdisciplinary Congress on Women's Studies, Sakarya University Press, 35-44.

[16] Kutanis, R.Ö. and Alparslan, S. (2006) Are Profiles of Women Entrepreneurs and Managers Different? Afyon Kocatepe University, Journal of IIBF, 8, 139-153.

[17] Terzioğlu, F. and Taşkın, L. (2008) Reflections of Social Gender Role on Female Leadership Behavior and Nursing Profession. Journal of Cumhuriyet University School of Nursing, 12, 62-67.

[18] Bridge, B. (2003) Women in Educational Management. Beyaz Yayınları, Istanbul.

[19] Karaca, A. (2007) Career Barriers for Women Executives-An Applied Research on Glass Ceiling Syndrome. Dissertation Thesis, Selçuk University, Konya. 
[20] Needle, D. (2010) Business in Context: An Introduction to Business and Its Environment. Cengage Learning EMEA.

[21] Ravasi, D. and Majken, S. (2006) Responding to Organizational Identity Threats: Exploring the Role of Organizational Culture. Academy of Management Journal, 49, 433-458. http://dx.doi.org/10.5465/AMJ.2006.21794663

[22] Bilimoria, D., Joy, S. and Liang, X.F. (2008) Breaking Barriers and Creating Inclusiveness: Lessons of Organizational Transformation to Advance Women Faculty in Academic Science and Engineering. Human Resource Management, 47, 423-441. http://dx.doi.org/10.1002/hrm.20225

[23] Lewis, A.E. and Fagenson, E.A. (1995) Strategies for Developing Women Managers: How Well Do They Fulfill Their Objectives? Journal of Management Development, 14, 39-53. http://dx.doi.org/10.1108/02621719510078885

[24] McKeen, C.A. and Richardson, A.F. (1992) Still Bumping Up against the Glass Ceiling. CMA Magazine, 66, 22-26.

[25] Zane, N.C. (2002) The Glass Ceiling Is the Floor My Boss Walks on Leadership Challenges in Managing Diversity. The Journal of Applied Behavioral Science, 38, 334-354. http://dx.doi.org/10.1177/0021886302038003005

[26] Anafarta, N., Sarvan, F. and Yapıcı, N. (2008) Perception of Glass Ceiling of Female Managers in the Hospitality Enterprises: A Survey in the City of Antalya. Akdeniz University Journal of Faculty of Economic and Administrative Sciences, 15, 111-137. 


\section{Appendix}

\section{CAM TAVAN ÖLÇEĞİ}

Kesinlikle katılmıyorum
Katılmıyorum Kararsızım Katılıyorum
Kesinlikle

katıliyorum

Kadının yeri eşinin yanında bulunmak ve iyi bir anne olmaktır.

Ev işlerinde eşit sorumluluk paylaşımı gereklidir.

Çalışma yaşamı bir kadının iyi bir anne ve eş olmasını önler.

Kadınların evli ya da çocuk sahibi olmaları performanslarını olumsuz yönde etkiler.

Şu anda ya da gelecekte çocuk sahibi olma düşüncesi kadınların kariyer hedeflerini sınırlar.

Kadınlar kariyer hedeflerini gerçekleştirmek için belirli bir plana sahiptirler.

Kadınlar için işlerinde ilerleme ve gelişme olanakları çok önemlidir.

Kadınlar başarılı bir yönetici olmak için gerekli yetenek, objektif görüş ve inisiyatife sahiptir.

Kadınlar üst düzey yönetici olduklarında yalnız kalma korkusu yaşarlar.

Üst düzey kadın yöneticiler, kadın olma özelliklerini yitirirler.

Kendine güveni olan kadınlar, üst yönetici

olmanın zorluklarını kolaylıkla aşarlar.

Kadınlar terfi etme ve daha yüksek pozisyonlara gelme konusunda isteksizdirler.

Kadınlar, maaş, prim, statü gibi konularda ayrımcilığa maruz kalırlar.

Üst düzey yöneticilik için erkeklere kadınlardan daha çok firsat sağlanmaktadır.

Kadınlar yeteneklerine göre daha düşük konumlarda çalıştırılmaktadır.

Kadınlar aynı konumdaki erkek çalışanlarla eşit ücret almaktadır.

Kadınlar yönetsel görevlere gelmelerini sağlayacak eğitim firsatlarından erkeklerle eşit şekilde yararlanmaktadır.

Personel çıkarılması gerektiğinde (kriz döneminde) öncelikle kadınlar işten çıkarılmalıdır.

Kurumda kadın ve erkeklere yönelik eşit performans değerleme politikaları mevcuttur.

Kurumda iş yaşamı erkeklerin kurallarıyla yönetilmektedir.

Kadınlar erkek iș arkadaşları ve üstleri ile rahat iletişim kurabilirler.

Erkekler genellikle resmi olmayan kurum dışı ilişsilerin etkisiyle kendi cinslerini kayırıcı davranışlarda bulunurlar.

Kadınlar erkek-baskın iletişim ağlarına girmekte zorlanmaktadır.

Kadınlara rol modeli olabilecek yeterli sayıda kadın yönetici yoktur.

Kurumda mentorluk iliş̧isinden kadınlar yeterince yararlanmaktadır.

Aileler kız çocuklarını kadınlara yönelik olduğunu düşündükleri mesleklere yöneltmektedir.

Kurum içinde görev dağılımı kadın ve erkek için farklılık arz etmektedir. 


\section{Continued}

Kadın çalışanlar mesleklerinde ilerleme konusunda erkeklere göre daha çok çalışmakta ve daha uzun süre beklemektedir.

Üst düzey yönetici kademelerine ulaşmada etkili olan kilit görevlerde, kadınlar yeterince yer almaktadır.

Kadınlar üst düzey yönetici olarak atanmamalıdır.

Erkekler kadınlara göre üst düzey yöneticilik konumuna daha uygundur.

Kadınlar kariyerlerine erkekler kadar bağlı değildirler.

Kadın yöneticiler hızlı ve mantıksal karar alamazlar.

Kadınlar yöneticilik özelliklerine sahiptir.

Kadınlar iş dünyasının güçlüklerine

erkekler kadar direnç gösteremezler.

Kadınlar erkeklere göre daha duygusal olduklarından üst düzey yöneticilikte başarılı olamazlar

Kadınlar uzun mesailere, sehirlerarası ya da ülkeler arası seyahatlere sıcak bakmazlar.

Kadınların yetenekleri üst düzey yönetici olmaları için sınırlıdır. 